\title{
GEOGRAPHICAL CONCEPTUALIZATION OF QUALITY OF LIFE
}

\author{
FRANTIŠEK MURGAŠ
}

Department of Geography, Faculty of Science, Humanities and Education, Technical University of Liberec, Studentská 2, 46117 Liberec, Czech Republic; e-mail: frantisek.murgas@tul.cz

\begin{abstract}
Murgaš F.: Geographical conceptualization of quality of life. Ekológia (Bratislava), Vol. 35, No. 4, p. 309-319, 2016.

The conceptualization of quality of life in terms of geography is based on two assumptions. The first assumption is that the quality of life consists of two dimensions: subjective and objective. The subjective is known as 'well-being', while the objective is the proposed term 'quality of place'. The second assumption is based on the recognition that quality of life is always a spatial dimension. The concept of quality of life is closely linked with the concept of a good life; geographers enriched this concept by using the term 'good place' as a place in which the conditions are created for a good life. The quality of life for individuals in terms of a good place overlaps with the quality of life in society, namely the societal quality of life. The geographical conceptualisation of quality of life is applied to settlements within the city of Liberec.
\end{abstract}

Key words: quality of life, quality of place, good life, Liberec.

\section{Introduction}

Quality of life is one of the current concepts, an attempt to understand the social and economic reality. This concept has two dimensions: subjective and objective, however, this distinction is rarely used. For the subjective dimension, psychologists generally use the terms 'well-being', 'happiness' and 'life satisfaction'. Economists and other scientists, who are concerned with space usage within the objective dimension, use terms such as economic well-being (Easterlin, 2014), objective well-being (D’Acci, 2014) or well-being of nations (Veenhoven, 2014b). Quality of life research has increased in the past two decades (Rapley, 2003; Sirgy, 2012), as a result of the need to restore the science of quality of life (Sirgy, 2012). The understanding of quality of life (and luck) dominates the researches in a positive sense. Although there were notions of ill-being (Pacione, 2003), examining negative well-being in a variety of symptoms (e.g., pain and suffering) is not common (Anderson, 2014, 2015; Glatzer, 2015). This fact is probably associated with the development and spread of positive psychology, which focuses on the positive mental phenomena of human life. In research, the focus on the quality of life in various settlements is increasing, while the quality of urban life (Frick et al., 1986; Pacione, 2003; Ira, Andráško, 2007; Andráško, 2008; Marans, Stimson, 2011; Berry, Okulicz-Kozaryn, 2011; Ira, 2015; Murgaš, 2013, 2014) far exceeds the quality of rural life (Spellerberg et al., 2007; D'Agostini, Fantini, 2008; Baránková et 
al. 2011; Špulerová et al. 2013; Böhm, 2015a,b; Jakubcová et al., 2016; Angelovič, Ištok, 2016). Another specialization with an increasing representation is the study of happiness (David et al., 2013; Veenhoven, 2014a), including geography of happiness (Mitchel et al., 2013; Hotová, Murgaš, 2014). On the other hand, the quality of life has become a 'shibboleth' in public discourse. Different scientific disciplines are dedicated to the quality of life as a study of the good life. Since geographers - even on a global scale - are not paying enough attention to the concept of objective dimension, notwithstanding that it should be at the centre of their interest, other experts, especially sociologists and economists, are exploring it. The reason why geography as a subject should deal with the quality of life is because of its focus on space. The phenomenon of a good place is related to this (McCann, 2004) as a place in which the good life is lived, to a varying degree (Veenhoven, 2014b). 'Place in general is a central concept of human geography' (Henderson, 2009, p. 539). For this reason, the term quality of place is used for the objective dimension focusing on space (Trip, 2007; Burton, 2014; Murgaš, Klobučník, 2016). Various rankings testify ${ }^{1}$ that states, regions or settlements can be regarded as good places; then we talk about the settlement quality of life.

The aim of the paper is to propose a draft of the geographical conceptualisation of quality of life and its ecological domain with their geographical applications.

\section{Theoretical background}

What is quality of life? It is a concept, a subjective thought-construction. It expresses how emotionally and cognitively we value our life on a scale of good to bad ${ }^{2}$. Quality of life ${ }^{3}$ is not the only term with which people express the evaluation of their life; it also applies to the public sector and researchers. Other commonly used terms are well-being (Pacione, 2003; Kearns, Andrews, 2010), or life satisfaction (Sirgy, 2012). The term subjective quality of life (McCrea et al., 2011; Sirgy, 2012) is also used to distinguish it from an objective dimension. In scientific papers, which are dedicated to dealing with health as a part of quality of life, quality of life is identified within the health domain. The Health-Related Quality of Life (HRQoL) is used for this domain. The term happiness has an independent status in the context of quality of life. However, quality of life cannot be equated with well-being, health and happiness because of its complexity and multidimensionality.

The basic element with which the concept of quality of life is closely linked is the concept of a good life (Ferris, 2010; Michalos, Robinson, 2012; Veenhoven, 2013; Widmer, 2014). For a good life, there is also the definition of quality of life - 'the degree to which a life meets various standards of good life' (Veenhoven, 2014b, p. 5265). The good life is associated with good society; conversely, the creation of a good society is the key to a good life. An important question is whether a welfare state is crucial for a good society (Ferris, 2010). The 'creation' of good life through a good society is a top-down approach. The problem is that opinions on what is a good society, as well as what is a good life, are diametrically different. On the other hand, a bottom-up approach involves creating conditions for a good life. It incorporates not only the

\footnotetext{
${ }^{1}$ UN Human Development Index, Happy Life Expectancy, The where-to-be-born index 2013 The Economist Intelligence Unit, OECD Better Life Index, etc.

${ }^{2}$ In eleventh Cantril's grade scale (0-bad 10-excellent) Westerners on average evaluate their lives at 7.5.

${ }^{3}$ Some authors (Kearns, Andrews, 2010; Pain, Smith, 2010) use the term quality of life.
} 
traditions of all the great world religions, but also knowledge of psychology. The most important aspect is the knowledge of factors determining the source of well-being. Fifty percent of well-being is genetically determined and forty percent of resources demonstrate intentional activity that is formed by a large variety of people's daily activities. Only ten percent of wellbeing is influenced by the physical environment and demographic and social characteristics of the regions in which people live (Lyubomirsky et al., 2005). The external environment with its characteristics and facilities creates a quality of place. Although its impact on quality of life is not decisive, it is not negligible either. Its importance underlines the fact that within states, and also on an international level, people move mainly to locations or countries that represent a high quality of place.

Geographers pay major attention to the concept of a place. Matlovič and Matlovičová (2006) cite Harvey (1996, p. 298, 261): importance of qualitative aspects of place increase, mainly the importance of a quality of life in a place as well as the meaning of creation of the city image and city marketing... Places must present themselves as a good place for life, work and investment. Matlovič (2007) presents a trinary conception of cities with three levels of the spheres. A good place is a place of high quality that meets the quality of life for individuals and the quality of life of the society or societal quality. According to Andrews (2001, p. 201), the quality of place is 'a comprehensive indicator of external environmental factors that contribute to quality of life. The quality of place can be described as emotional and cognitive assessment of external, material and immaterial conditions for human life. Usually, the term 'quality of place' is used in different contexts, such as creative class (Florida, 2002), urban development (Trip, 2007; Burton, 2014), economic development (Reily, Renski, 2008), and quality of life (Pacione, 2003; Azevedo et al., 2013). Murgaš and Klobučník (2016) propose the term of quality of place for the objective dimension of quality of life, as psychologist use for the subjective dimension the term of well-being. The quality of place can be described as the emotional and cognitive assessment of external, material and immaterial conditions for quality of life.

In general, quality of life does not have any accepted definitions, methodology or terminology. One of the main reasons for this is that the methodological development of quality of life is significantly lagging behind its applications. According to Heřmanová $(2012$, p. 41) 'the quality of life as perceived and lived by individuals is a reflection of objective environmental conditions (the external environment) and self-reflection (the internal environment) of humans in the context of cultural, valuable, social and spatial (geographical) systems, and in relation to individual motivation, capabilities, goals and expectations.' The above definition of quality of life, created by the geographer, is an effort of a holistic understanding of quality of life, which is not shown by authors who are not geographers. Easterlin and Angelescu (2012, p. 113) define it: 'The quality of life involves multiple dimensions of human experience that affect well-being'. According to Veenhoven (2014b, p. 5265), the quality of life is 'the degree to which a lifetime meets various standards of good life.'

Dimensions are in the methodology of the quality of life and its part at the highest hierarchical level. There are two dimensions of quality of life: subjective (well-being) and objective (quality of place). Well-being expresses the subjective, emotional survival and evaluation of satisfaction with its own life. Time-space variability comes from subjectivity of evaluation. Out of both dimensions, well-being is more important (Casas et al., 2004; Sirgy, 2012), while qual- 
ity of place is also necessary for the assessment of quality of life (Sirgy, 2012). The structure of dimensions, domains and indicators (variables) of quality of life is shown in Table 1.

$\mathrm{T} \mathrm{a} \mathrm{b} \mathrm{l} \mathrm{e} \mathrm{1.} \mathrm{The} \mathrm{structure} \mathrm{of} \mathrm{dimensions,} \mathrm{domains} \mathrm{and} \mathrm{indicators} \mathrm{of} \mathrm{quality} \mathrm{of} \mathrm{life.}$

\begin{tabular}{|l|c|c|}
\hline Hierarchy & characteristic & examples \\
\hline Dimensions & Domain clusters & Well-being, quality of place \\
\hline Domains & Indicator clusters & Demographic, education, environment facility \\
\hline Indicators & Individual variables & Life expectancy, emissions, divorce, education \\
\hline
\end{tabular}

The relationship between the alternatives to well-being values and quality of place is reflected in Table 2 in a simplified form. An inspirational statement in relation to quality of place has been given by Andrews (2001). According to him, the parameters of quality of place differ in good and bad times.

$\mathrm{T}$ a b l e 2. Relationship opportunities amongst dimensions of quality of life.

\begin{tabular}{|l|c|c|}
\hline \multirow{2}{*}{ Quality of place } & \multicolumn{2}{|c|}{ Well-being } \\
\cline { 2 - 3 } & Good & Bad \\
\hline Good & WELL-BEING & DISSONANCE \\
\hline Bad & ADAPTATION & DEPRIVATION \\
\hline
\end{tabular}

Source: Adapted according to Rapley (2008). In the original text, Quality of Place is called Objective Living Conditions.

In good times, when people are satisfied with their personal and professional life, they are interested in the facilities of a place, opportunities for recreation, friendly neighbourhood communities and a pleasant environment. Conversely, in bad times people are primarily concerned with the availability of jobs, food, housing and security.

Domains represent the medium hierarchical level in quality of life methodology (clusters of indicators with internal causality); indicators represent the lowest hierarchical level. Ira and Šuška (2006, p. 311) understand domains as 'the main ingredients that help shape a whole'. Quality of life indicators are the variables important for its (domain) measurement. The high number of domains and indicators used in quality of life research relate to the methodological uncertainty of this concept. The presence of indicators of well-being and quality of place are required for the measurement of holism of quality of life. The lowest number of indicators with the highest denouncing value is generally considered as the target state. Herrmanová (2012) states an overview of used domains and indicators.

The geographic approach to quality of life is based on the premise that quality of life has its own spatial dimension. Schwanen and Atkinson (2015) state that geographers play a key role in the discussions about the governance of well-being. The Human Geography Research Group of the University of Edinburgh is an example of a workplace that is concerned with the quality of life. The geographies of health and well-being are considered as one of six parts of 
human geography. The connection between quality of life and health is common (Rapley, 2008; Castelli et al., 2009). However, the quality of life also enters into many other geographic phenomenon, for example ageing (Bucher, 2016), social quality (Antalová, 2015), and standards of living (Aivazian, 2016).

Some authors (Kearns, Andrews, 2010; Pain, Smith, 2010; Schwanen, Atkinson, 2015; Florida, 2015) use 'geography of well-being' as a term. This term is meaningful when it expresses the geography of personal and subjective dimensions of quality of life. Psychologists call it wellbeing and other sciences downloaded this psychological term. The geography of quality of life is an adequate term for the quality of life as a holistic concept. So for example, regarding spatial differentiation of the Human Development Index in the USA (Florida, 2015) - which of course is not about spatial differentiation of well-being but about the quality of life - it is methodologically correct to say 'geography of quality of life' rather than 'geography of well-being'.

Two directions evolved during the development of quality of life research: social and economic. Both have a common platform that is space (Kominácká, 2011). A space results in personal evaluation of quality of life at different hierarchical levels, starting from the micro level of a rural village or the urban district of a city, to the mezzo level of districts, up to the macro level of regions or states. Micro level - local level - is the place where every day human activities take place. At this level, the impact of space is most intense; man assesses it according to the emotional, psychological and sociological criteria. The result is a positive correlation to the place, Yi-Fu Tuan labelled it as 'topophilia' or negative, Ruan and Hogben named it as 'topophobia' (Siwek, 2011). Human activities mainly take place at a mezzo level, in terms of quality of place. The space is reflected, but its perception is not intense. At a macro level - considered state level - space is reflected at a low level. Rare events such as political changes or natural disasters are exceptional. For every human, the perception of space is assessed as a part of quality of life. Mental maps can be considered as a geographical expression of spatial perception, an objective dimension of quality of life. Differentiation of quality of life is projected into maps; however, there is another aspect of space autocorrelation (Slavík et al., 2011; Klobučník, Slavík, 2013).

Geographers strive as a priority to provide information about where the quality of life is high, medium or low. Geographers do not have the tools of psychologists and social psychologists to identify how the quality of life arises. However, they can comment upon how the external environment affects it, and how it is spatially differentiated. Their sphere is the external environment of humans, and the feedback between man and the quality of life, resulting in a phenomenon mentioned in the introduction of 'good place' as a place where people 'live well'. The existence of feedback demonstrates the attractiveness of a place. This attractiveness can be considered as 'place output' of quality of life; in geographical terminology, it is understood as the relationship of quality of life with other elements of the geographical sphere. In countries with a tradition of high spatial mobility of the population, such as the USA, quality of life is one of the important reasons for immigration (Rappaport, 2009).

Pacione (2003, p. 23) states nine problematic areas identified by geographers in relation to the quality of life. The main ones are: (i) performing basic measurements of quality of life, allowing time comparisons, (ii) the knowledge of differentiation between satisfaction and dissatisfaction in society and space and (iii) an understanding of how people combine their perception of issues of their lives with the overall assessment of quality of life. 
Along with the study of spatial differentiation of quality of life in different hierarchical levels, an important part of geographical quality of life research is the quality of urban life research. In different regions, particularly on a hierarchical level of large regions (regions or countries), personal dimensions of quality of life recede into the background in comparison with spatial dimensions. Regarding cities, both dimensions are at a balanced ratio, considering the quality of their urban life. This means that the concept of quality of urban life is the closest to the ideal, which is a holistic understanding of quality of life.

Concepts such as environment, sustainable development, environmental protection, nature conservation or ecology are interchangeable in public and academic discourse. We understand them synonymously as a part of the environmental domain in the context of the quality of life. One of the possible perceptions of ecology comes from the Anglo-Saxon and Scandinavian understandings that focus on human attitudes, perceptions and understanding of nature and man's place in it. This perspective is known as environmental ethics (Kohák, 2006).

There is an important relationship between quality of life and ecology. The understanding of ecological crisis as an inevitable clash of the finite world and the infinite right to grow (Murgaš, $2014)$ is naturally reflected by this relationship. According to Kohák (2006, p. 65) 'the adoration of consumption in contemporary consumer society takes the form of "affluenza epidemic", a deadly epidemic of excess. Is the idea that the only purpose of life and almost a moral duty to citizens is to accumulate and consume more and more tangible assets? Is the desire for 'more' natural?, asks the author and matches: No, but satisfies the conditions of the consumer society, which fashionable thinkers like to refer to as "postmodern"' - a distracted, fickle society that is still hungry for'. This understanding of ecology is significantly associated with a eudemonic quality of life; their intersection has the same value basis. An expression of the intersection is the quality of place as a place where a good life is lived (Murgaš, Klobučník, 2016).

According to Murgaš (2015), there are two key questions in the relationship of quality of life and sustainability. The first one is: what kind of life, specifically, do we want to maintain? Nowadays in wealthy Western countries, a large proportion of the population survives in a material excess and lives a hedonistic and prodigal way of life. Does sustainability mean that we want to maintain this way of life? The second question relates to the first one: What are the indicators with which we can measure what we want to keep? We think that quality of life cannot be identified with sustainability or ecology. Considering the number of common elements, they also have differences. While sustainability is focused mainly on the future, quality of life is primarily focused on the present. Another difference is the position of the environment indicator. Environment is one of the numerous indicators in the measurement of quality of life, while sustainability is a key element.

\section{Results}

Geographical access to quality of life is successfully applied at different hierarchical levels, starting from settlements (Ira, Šuška, 2006; Ira, Andráško, 2007; Heřmanová, 2012; Ira, 2015; Kladivo, Halás, 2012) to the districts and regions (Ira et al., 2006; Murgaš, 2009; Murgaš, Klobučník, 2016). Settlements and regional units were analysed as good places to live. In 2016, a research was carried out in Liberec which focussed on the assessment of personal well-being, as well as 
satisfaction with the quality of Liberec as a good place to live. The questionnaire developed by the author of the contribution was used in the research. There were 515 residents older than 18 years involved in the research. Within the research of quality of place in the settlements of the Czech Republic (Murgaš, Klobučník, 2016), Liberec reached the value of 6.41 (out of 10). The average value of the regional cities was 6.38; the average value of all the settlements was 5.29. Within the research in Liberec, the answer to the question 'How would you express satisfaction with your life?' was considered as the quality of urban life. Please, indicate the number on a scale from 0 to 10 , where 0 is an absolute dissatisfaction and 10 is an absolute satisfaction. Quality of life in Liberec reached the value of 7.5 (out of which, 7.4 was for men and 7.6 for women). In addition to the assessment of well-being, we asked the residents about their satisfaction with life in Liberec, that is to say, on the assessment of Liberec from the point of view of quality of place (Table 3). It follows from the above that the primary data about well-being of inhabitants of Liberec and also their satisfaction with life in the city has higher values than the value of Liberec, in terms of quality of place identified from the secondary data.

T a b l e 3. Satisfaction with life in Liberec (\%).

\begin{tabular}{|l|c|c|c|}
\hline \multirow{2}{*}{ Satisfaction } & \multicolumn{2}{|c|}{$\%$} & men \\
\cline { 2 - 4 } & average & 41 & 32 \\
\hline Very satisfied & 36 & 40 & 47 \\
\hline Mostly satisfied & 44 & 17 & 17 \\
\hline Neither satisfied nor dissatisfied & 17 & 2 & 4 \\
\hline Mostly dissatisfied & 3 & $\mathrm{x}$ & 0 \\
\hline Very dissatisfied & 0 & & \\
\hline
\end{tabular}

Note: $\mathrm{x}$-data did not occur.

\section{Discussion}

All people look for quality, that is a good life, but everybody has a different idea about its content. The term good life has been used by ancient authors; the desire to live well is the archetypal human desire. At the same time, the quality of life has become an overused and empty concept in public discourse. The final chapter of a Rappley's monograph (Rapley, 2008, p. 212) entitled 'Should We "Hang up Quality of Life as a Hopeless Term"?' - is it therefore important to deal with quality of life scientifically? Overused, eventually the emptying of the content of quality of life concept is linked with an intuitive relationship of the public against it, just as it was at the previous concept of the environment, or the actual phenomenon of globalization, which is currently part of the normal spoken language. In the production of scientific articles and monographs, those which are application oriented strongly dominate, resulting in a lagging behind of methodology and quality of life theory. A complexity of quality of life, in terms of having links between two dimensions and the need for a holistic approach to it are the only aspect mentioned.

For geography as a subject, the quality of life is an important opportunity to increase its importance in society. The quality of life is one of the key concepts of public and decision-making sphere interest, and that logically raises the demand for its outputs. According to some authors (Pacione, 2003; Van Kamp et al., 2003; McCann, 2004; Kominácká, 2011; Murgaš, 2012), space 
is a factor with a significant impact on quality of life. A quantification of the quality of life index in settlements of the Czech Republic (Murgaš, Klobučník, 2016) and from this, the resulting indexes of quality of life on a hierarchical level of districts and regions are based on a gold standard model of quality of life with ten indicators (Murgaš, 2012). The results provide valid information about the achieved levels of objective conditions for a good life on a decisionmaking level. Improving these conditions should be the primary content of public policy at all decision-making levels. The academic sphere should have the ambition and ability to explain the large differences among settlements. The amount of differences are four and a half times among the municipalities with the highest and the lowest value on the quality of life index, which is for a state the size of the Czech Republic - unfounded, as well as the differences in the level of districts and regions. The second task for the academic sphere should be the ability to explain the large differences among neighbouring districts. Geographers might approach these tasks only as a necessity for the development of their own methodological approaches to quality of life.

\section{Conclusion}

The aim of the paper is to propose a draft of the geographical conceptualisation of quality of life and its ecological domain with their geographical applications. The reason why geography should deal with quality of life is its focus on space. With this is related the phenomenon of a good place as a place, in which good society (Ferris, 2010) to a varying degree, lived a good life (Veenhoven, 2014b). Therefore, geographers Murgaš and Klobučník (2016) used a label quality of place for the subjective dimension, focusing on space. A good place might be settlements, at which point we talk about quality of life of settlements or regions on different hierarchical levels. Due to the dominance of towns in settlement structures, the quality of life of settlements generally has the shape of quality of urban life (Marans, Stimson, 2011).

A conceptualization of quality of life is based on the term 'good life' (McCann, 2004; Ferris, 2010; Michalos, Robinson, 2012; Veenhoven, 2014b). The hierarchical structure of quality of life, in terms of dimensions, domains and indicators, is proposed in the paper. The general consensus in the study of quality of life is in identification of its two dimensions - personal, which is operationalized as well-being and spatial, and also as quality of place. The personal dimension is considered to be the most important; however, the holistic research of both dimensions is also necessary. Geographical applications of the quality of life concept are discussed in the next section. The geographical approach to quality of life is based on the premise that the quality of life always has a geographic dimension that is firstly planned in its spatial dimension and secondly planned in its personal dimension. In the development of quality of life, two directions have been formed - social and economic. Both have a common platform which is space. Geographers especially are expected to provide data about this, where the quality of life is high, medium or low. Geographers do not have the tools of psychologists and social psychologists to identify how the quality of life arises. However, they can comment on what it saturates and how it is spatially differentiated. Their sphere is man's external environment manifested by the quality of place in terms of a phenomenon of 'good place' as a place where people 'live well', which was mentioned in the introduction. 
Geographical application, which examines the quality of life at different hierarchical levels, can deliver results for decision-making sphere and for the public, but the development of theoretical assumptions of geography of quality of life is essential.

Acknowledgements

I would like to thank two anonymous referees for their useful comments on earlier versions of this article.

\section{References}

Aivazian, S. A. (2016). Quality of life and living standards analysis. An econometric approach. Berlin, Boston: Walter de Gruyter.

Anderson, R.A. (2014). Human suffering and quality of life. Conceptualizing, stories and statistics. Dordrecht: Springer. Anderson, R.A. (2015). Global decline in well-being. Social Indicators Network News, 125, 1-9.

Andráško, I. (2008). The role and status of geography in the quality of life research. In V. Poštolka, Z. Lipský, K. Popková \& J. Šmída (Eds.), GEODNY LIBEREC 2008: Zborník př́spěvků (pp. 210-215). Liberec: Technická univerzita v Liberci.

Andrews, C.J. (2001). Analysing quality-of-place. Environment and Planning B: Planning and Design, 28, $201-217$. DOI: $10.1068 / \mathrm{b} 2714$.

Angelovič, M. \& Ištok R. (2016). How to assess quality of life. Theoretical and methodological research aspects in crossborder regions. Bulletin of Geography. Socio-economic Series, 32, 19-32. DOI: 10.1515/bog-2016-0012.

Antalová, M. (2015). Kvalita života v kontexte sociálnej kvality. In F. Murgaš (Ed.), Kvalita života 2015. Sborník přispěvků z česko-slovenské vědecké konference 2. a 3. 12. 2015 v Liberci. CD Room. Liberec: Technická univerzita v Liberci.

Azevedo, A.J.A. de, Custódio, M.J.F. \& Perna F.P.A. (2013). “Are you happy here?”: the relationship between quality of life and place attachment”. Journal of Place Management and Development, 6(2), 102-119. DOI: 10.1108/JPMD06-2012-0017.

Baránková, Z., Dobrovodská, M., Štefunková, D., Babicová, D., Moyzeová, M. \& Petrovič F. (2011). Participation on identifying the landscape values and future development in historical agricultural landscapes. Ekológia (Bratislava), 30(2), p. 216-228. DOI: 10.4149/ekol_2011_02_216.

Berry, B.J.L. \& Okulicz-Kozaryn A. (2011). An urban-rural happiness gradient. Urban Geography, 32(6), 871-883. DOI: $10.2747 / 0272-3638.32 .6 .871$.

Böhm, H. (2015a). Czech-Polish borders: Comparison of the EU funds for cross-borders cooperation of schools in selected Euroregions. Esztergom: European Institute of Territorial Cooperation.

Böhm, H. (2015b). New forms of cross-border cooperation governance as a tool of environmental protection strategies - example from Czech-Polish-Slovak borders. In International multidisciplinary geosciences conference proceedings (p. 356). Albena.

Bucher, S. (2016). Ageing of the population in the Russian Federation: The current trends and indicators. Herald of the Russian Academy of Sciences, 86(2), 97-104.

Burton, M. (2014). Quality of place. In A.C. Michalos (Ed.), Encyclopaedia of quality of life and well-being research (pp. 5212-5315). Dordrecht: Springer.

Casas, F., Figuer, M., Gonzáles, M. \& Coenders G. (2004). Satisfaction with life domains and salient values for the future. Analyses about children and their parents. In W. Glatzer, S. von Bellow \& M. Stofferegen (Eds.), Challenges for quality of life in the contemporary world. Advances in quality-of-life studies, theory and research (pp. 233-248). Dordrecht: Springer.

Castelli, A., Jacobs, R., Goddard, M. \& Smith P.C. (2009). Geographical variation in quality of life: The role of public service organisations. Retrieved February 21, 2016, from World Wide Web: https://ww w.york.ac.uk/media/che/ documents/policybriefing/Variations\%2 0in\% 20QOL_fin a l.pdf.

D'Acci, L. (2014). Well-being and progress measurement. In A.C. Michalos (Ed.), Encyclopaedia of quality of life and well-being research (pp. 7062-7070). Dordrecht: Springer.

D' Agostini, A. \& Fantini A.C. (2008). Quality of life and quality of living conditions in rural areas: Distinctively perceived and quantitatively distinguished. Social Indicators Research, 89(3), 487-499. DOI: 10.1007/s11205-008-9245-4. 
David, S.A., Boniwell, I. \& Conley Ayers A. (Eds.) (2013). The Oxford handbook of happiness. Oxford: Oxford University Press.

Easterlin, R.A. \& Angelescu L. (2012). Modern economic growth and quality of life: Cross-sectional and time series evidence. In K.C. Land, A.C. Michalos \& M.J. Sirgy (Eds.), Handbook of social indicators and quality of life research (pp. 113-136). Dordrecht: Springer.

Easterlin, R.A. (2014). An economist's road to subjective well-being. Applied Research in Quality of Life, 9(3), 783-785. DOI: $10.1007 / \mathrm{s} 11482-014-9329-\mathrm{z}$.

Ferris, A. (2010). Approaches to improving the quality of life. How to enhance the quality of life. Dordrecht: Springer.

Florida, R. (2002). The rise of the creative class, and how it's transforming work, leisure, community and everyday life. New York, NY: Basic Books.

Florida, R. (2015). Geography of well-being. Retrieved December 14, 2015, from World Wide Web http://www.citylab. com/work/2015/04/the-geography-of-well-being/391188/.

Frick, D., Hoefert, H-E., Legewie, H., Mackensen, R. \& Silbereisen K. (1986). The quality of urban life. Social, psychological, and physical condition. Berlin, New York: Walter de Gruyter.

Glatzer, W. (2015). Worries and pain - The dark side of quality of life. In W. Glatzer, L. Camfield, V. Møller \& M. Rojas (Eds.), Global handbook of quality of life. Exploration of well-being of nations and continents (pp. 855-868). Dordrecht: Springer.

Henderson, G. (2009). Place. In D. Gregory, D. Johnston, G. Pratt \& M. Watts (Eds.), The dictionary of human geography (pp. 539-541). Chichester: Wiley-Blackwell.

Heřmanová, E. (2012). Koncepty, teorie a měření kvality života. Praha: SLON.

Hotová, T. \& Murgaš F. (2014). Geografie štěstí. In F. Murgaš (Ed.), Kvalita života v regionech České republiky (pp. 41-54). Liberec: Technická univerzita v Liberci.

Ira, V., Podolák, P. \& Michálek A. (2006). Kvalita života a životné prostredie človeka. In J. Mládek, D. Kusendová, J. Marenčáková, P. Podolák \& B. Vaňo (Eds.), Demografická analýza Slovenska (pp. 142-144). Bratislava: Univerzita Komenského v Bratislave.

Ira, V. \& Šuška P. (2006). Percepcia kvality života v mestskom prostredí (na príklade mesta Partizánske). Geografická Revue, 2, 309-332.

Ira, V. \& Andráško I. (2007). Kvalita života z pohladu humánnej geografie. Geografický Časopis, 59, 159-179.

Ira, V. (2015). Petržalka and quality of life of its inhabitants (Subjective dimension of assessment) (in Slovak). Životné Prostredie, 49(2), 82-86.

Jakubcová, A., Grežo, H., Hrešková, A. \& Petrovič F. (2016). Impacts of flooding on the quality of life in rural regions of Southern Slovakia. Applied Research in Quality of Life, 11(1), 221-238. DOI: 10.1007/s11482-014-9363-x.

Kearns, R.A. \& Andrews G. (2010). Geographies of wellbeing. In S.J. Smith, R. Pain, S. Marston \& J.P. Jones III (Eds.), The SAGE handbook of social geographies (pp. 309-328). London: SAGE.

Kladivo, P. \& Halás M. (2012). Quality of life in an urban environment: A typology of urban units of Olomouc. Quaestiones Geographicae, 31(2), 49-60. DOI: 10.2478/v10117-012-0018-4.

Klobučník, M. \& Slavík V. (2013). Identifikácia historicky osídlených regiónov Slovenska s využitím konceptu priestorovej autokorelácie. Geografický Časopis, 65(4), 341-362.

Kohák, E. (2006). Zelená svatozářr. Praha: SLON.

Kominácká, J. (2011). Moderní informační technologie pro podporu vyhodnocení prostorových indikátorů kvality života. Aplikace ve venkovské krajině jižní Moravy. Brno: Konvoj.

Lyubomirsky, S., Sheldon, K.M. \& Schkade D. (2005). Pursuing happiness: The architecture of sustainable change. Review of General Psychology, 9(2), 111-131. DOI: 10.1 037/1089-2680.9.2.111.

Marans, R.W. \& Stimson R.J. (2011). Investigating quality of urban life: Theory, methods, and empirical research. Dordrecht: Springer.

Matlovič, R. (2007) Hybridná idiograficko-nomotetická povaha geografie a koncept miesta s dôrazom na humánnu geografiu. Geografický Časopis, 59(1), 3-22.

Matlovič, R. \& Matlovičová, K. (2006). Koncept miesta vo vývoji geografického myslenia. In Kraft, S., Mičková, K., Rypl, J., Švec, P., Vančura, M. (eds.): Česká geografie v Evropském prostoru, sborník příspěvků XXI. Sjezdu České geografické společnosti. České Budějovice: Jihočeská univerzita.

McCann, J.E. (2004). 'Best Places': Interurban competition, quality of life and popular media discourse. Urban Studies, 41(10), 1909-1929. DOI: 10.1080/0042098042000256314.

McCrea, R., Shyy, T-K. \& Stimson R. (2006). What is the strength of the link between objective and subjective indicators of urban quality of life? Applied Research in Quality of Life, 1(1), 79-96. DOI: 10.1007/s11482-006-9002-2. 
Michalos, A.C. \& Robinson S.R. (2012). The good life: Eighth century to third century BCE. In K.C. Land, A.C. Michalos \& M.J. Sirgy (Eds.), Handbook of social indicators and quality of life research (pp. 23-62). Dordrecht: Springer.

Mitchell, L., Frank, M.R., Harris, K.D., Dodds, P.S. \& Danforth C.M. (2013). The geography of happiness: Connecting twitter sentiment and expression, demographics, and objective characteristics of place. PLoS ONE, 8(5), e64417. DOI: 10.1371 /journal.pone.0064417.

Murgaš, F. (2009). Priestorová diferenciácia kvality života na Slovensku. Geografický Časopis, 61(2), 121-138.

Murgaš, F. (2012). Prostorová dimenze kvality života. Liberec: Technická univerzita v Liberci.

Murgaš F. (2013). Několik poznámek ke kvalitě urbánního života. In F. Murgaš (Ed.), Kvalita života 2013, Sborník př́spěvků z mezinárodní konference 4. a 5. 12. 2013 v Liberci (pp. 97-106). Liberec: Technická univerzita v Liberci.

Murgaš, F. (2014). Kvalita urbánního života jako holistický koncept. Př́ípadová studie Liberec. In F. Murgaš (Ed.), Kvalita života v regionech České republiky (pp. 102-109). Liberec: Technická univerzita v Liberci.

Murgaš, F. (2015). Environmental indicator as a part of the golden standard of quality of life. In $15^{\text {th }}$ International multidisciplinary scientific GeoConference SGEM 2015, Ecology, Economics, Education and Legislation (pp. 251-258). Conference Proceedings, Vol. III. 18-24 June, 2015. Albena, Bulgaria.

Murgaš, F. \& Klobučník M. (2016). Municipalities and regions as good places to live: Index of quality of life in the Czech Republic. Applied Research in Quality of Life, 11(2), 553-570. DOI: 10.1007/s11482-014-9381-8.

Pacione, M. (2003). Urban environmental quality and human wellbeing - a social geographical perspective. Landsc. Urban Plann., 65, 19-30. DOI: 10.1016/S0 16 9-2046(02)00234-7.

Pain, R. \& Smith S.J. (2010). Introduction: Geographies of wellbeing. In S.J. Smith, R. Pain, S. Marston \& J.P. Jones III (Eds.), The SAGE handbook of social geographies (pp. 299-308). London: SAGE.

Rapley, M. (2008). Quality of life research. A critical introduction. London: SAGE.

Rappaport, J. (2009). The increasing importance of quality of life. Journal of Economic Geography, 9(6), 779-804. DOI: $10.1093 /$ jeg/lbp009.

Reilly, C.J. \& Renski H. (2008). Place and prosperity: Quality of place as an economic driver. Maine Policy Review, $17(1), 12-25$.

Schwanen, T. \& Atkinson S. (2015). Geographies of wellbeing: an introduction. The Geographical Journal, 181(2), 98-101. DOI: 10.1111/geoj.12132.

Sirgy, M.J. (2012). The psychology of quality of life. Hedonic well-being, life satisfaction, and eudaimonia. Dordrecht: Springer.

Siwek, T. (2011). Percepce geografického prostoru. Praha: Česká geografická společnost.

Slavík, V., Grác, R. \& Klobučník M. (2011). Priestorová autokorelácia - metóda vymedzovania a klasifikácie regiónov v kontexte sociálno-ekonomickej regionalizácie Slovenskej republiky. Sociológia, 43(2), 183-204.

Spellerberg, A., Huschka, D. \& Habich R. (2007). Quality of life in rural areas. Processes of divergence and convergence. Social Indicators Research, 83, 283-307. DOI: 10.1007/s11205-006-9057-3.

Špulerová, J., Dobrovodská, M., Izakovičová, Z., Kenderessy, P., Petrovič, F. \& Štefunková D. (2013). Developing a strategy for the protection of traditional agricultural landscapes based on a complex landscape-ecological evaluation (the case of a mountain landscape in Slovakia). Moravian Geographical Reports, 21(4), 15-26. DOI: 10.2478/ mgr-2013-0017.

Trip, J.J. (2007). Assessing quality of place: a comparative analysis of Amsterdam and Rotterdam. Journal of Urban Affairs, 29(5), 501-517. DOI: 10.1111/j.1467-9906.20 07.00362.x.

Van Kamp, I., Leidelmeier, K., Marsman, G. \& de Hollander A. (2003). Urban environmental quality and human wellbeing: Towards conceptual framework and demarcation of concept, a literature study. Landsc. Urban Plann., 65, 5-18. DOI: 10.1016/S01 69-2046(02)00232-3.

Veenhoven, R. (2013). Notions of the good life. In S.A. David, I. Boniwell \& A. Conley Ayers (Eds.). The Oxford handbook of happiness (pp. 161-173). Oxford: Oxford University Press.

Veenhoven, R. (2014a). Happiness. In: A.C. Michalos (Ed.) Encyclopaedia of quality of life and well-being research (pp. 2637-2641). Dordrecht: Springer

Veenhoven, R. (2014b). Quality of life (QOL), an overview. In A.C. Michalos (Ed.), Encyclopaedia of quality of life and well-being research (pp. 5265-5268). Dordrecht: Springer.

Widmer, M. (2014). Theories of good life. In A.C. Michalos (Ed.), Encyclopedia of quality of life and well-being research (pp. 2589-2592). Dordrecht: Springer 